\title{
Pre-clinical interaction of ayahuasca, a brew used in spiritual movements, with morphine and propofol
}

\author{
Júlia Movilla Pires ${ }^{1,2}$, Fúlvio Rieli Mendes ${ }^{3 *}$, Ana Paula Salum Pires ${ }^{4}$, Maurício Yonamine ${ }^{4}$, \\ José Luiz Gomes do Amaral ${ }^{1}$, Elisaldo Araújo Carlini²
}

\begin{abstract}
${ }^{1}$ Department of Surgery, Discipline of Anesthesiology, Pain and Intensive Care, University of São Paulo, São Paulo, Brazil, ${ }^{2}$ CEBRID, Department of Preventive Medicine, Federal University of São Paulo, São Paulo, Brazil, ${ }^{3}$ Center of Natural Sciences and Humanities, Federal University of ABC, São Bernardo do Campo, Brazil, ${ }^{4}$ Department of Clinical and Toxicological Analysis, School of Pharmaceutical Sciences, University of São Paulo, São Paulo, Brazil
\end{abstract}

\begin{abstract}
Ayahuasca is a beverage with psychoactive properties used in religious and ceremonial rituals by some religious groups. The main active components of ayahuasca are dimethyltryptamine and the harmala alkaloids with $\beta$-carboline structure acting as monoamine oxidase $\mathrm{A}$ inhibitors. This combination produces a pronounced activation of serotonergic pathways and presents potential interaction with other psychotropics. The objective of this study was to investigate the possible interactions between ayahuasca and agents employed in general anesthesia. The pharmacological interactions between ayahuasca and morphine or propofol were evaluated in mice using doses of 12,120 and $1200 \mathrm{mg} / \mathrm{kg}(0.1$ to 10 times the average dose consumed by humans in religious rituals). Ayahuasca alone showed an antinociceptive effect in the writhing and formalin tests, and intensified the analgesic effect of morphine in the hot plate test. Concerning the pharmacological interactions between ayahuasca and propofol, the results were opposite; ayahuasca intensified the depressant effect of propofol in the rotarod test, but decreased the sleeping time induced by propofol. These set of results showed the occurrence of some interactions between ayahuasca and the drugs morphine and propofol, possibly by both pharmacokinetics and pharmacodynamics mechanisms.
\end{abstract}

Keywords: Ayahuasca. Analgesic effect. Pharmacological interactions. Morphine. Propofol. $\beta$-Carbolines.

\section{INTRODUCTION}

Ayahuasca is a beverage with psychoactive properties prepared by decoction of two Amazonian plants, the vine of Banisteriopsis caapi (Spruce ex Griseb.) CV Morton (Malpighiaceae) and the leaves of Psychotria viridis (Ruiz \& Pav.) (Rubiaceae) utilized in ceremonial contexts of groups like Santo Daime, União do Vegetal, among others. The religious use of ayahuasca is legally accepted in Brazil and also occurs in the United States and Europe (Labate, Feeney, 2012). Participants generally meet two to three times per month for the realization of a religious cult and they consume one or two cups of ayahuasca brew at the beginning of the ritual, but the amount of ayahuasca taken in a session may vary among

\footnotetext{
*Correspondence: F. R. Mendes. Centro de Ciências Naturais e Humanas. Universidade Federal do ABC. Rua Arcturus, 03, São Bernardo do Campo, 09606-070, Brazil. E-mail: fulviorm@hotmail.com. Phone: + 5511 2320-6262
}

the individuals and depending on the concentration of the beverage (McKenna, 2004). There is no official statistics about ayahuasca misuse, but it is reported that its use has expanded on the last decades and it is present in at least 38 countries (Labate, Feeney, 2012; Domínguez-Clavé et al., 2016).

The main active components of ayahuasca are $N, N$ dimethyltryptamine (DMT) and the harmala alkaloids with $\beta$-carboline structure, harmine, harmaline, tetrahydroharmine (THH), and harmol, as well harmalol in trace amounts (Callaway, Brito, Neves, 2005). DMT is present in the leaves of $P$. viridis and, when taken orally, it is rapidly inactivated by monoamine oxidase A (MAO-A) in the bowel and liver, which is avoided with the combination of $\beta$-carbolines present in $B$. caapi acting as MAO inhibitors (MAOI) (McKenna, Towers, Abbott, 1984). DMT is a potent $5-\mathrm{HT}_{1 \mathrm{~A}}, 5-\mathrm{HT}_{2 \mathrm{~A}}$ and $5-\mathrm{HT}_{2 \mathrm{C}}$ receptor agonist and also interact with other molecular targets (Frecska, Bokor, Winkelman, 2016; Domínguez-Clavé et al., 2016). In 
addition, THH is believed to act as selective inhibitor of serotonin reuptake (Frecska, Bokor, Winkelman, 2016). The result of this interaction is a pronounced stimulation of serotonergic pathways leading to possible therapeutic potential, but also to potential interactions with other central nervous system drugs (Domínguez-Clavé et al., 2016).

The anxiolytic properties of ayahuasca are described both in preclinical and clinical studies (Santos et al., 2007; Santos et al., 2016) and may be related with its serotonergic activity. According to information from members of the ayahuasca groups, it is a common procedure to drink a glass of ayahuasca before surgery to reduce anxiety and promote calmness (R. Guiso, personal communication), which makes relevant to evaluate possible interactions between the beverage and agents used in anesthesia. It is noteworthy that there is no medical literature assessing the safety of anesthetic procedures in patients who use ayahuasca.

It was shown that ayahuasca components interfere with cerebral levels of monoaminergic and aminoacidergic neurotransmitters, including GABA (Castro-Neto et al., 2013). Since some selective inhibitors of serotonin reuptake, antipsychotics and other psychotropics are metabolized by CYP2D6 that also metabolizes harmine and harmaline, the concomitant use of these substances may be problematic and should be avoided (Callaway, Grob, 1998; Callaway, 2005; Jiang et al., 2013). Moreover, it is known that MAOI may increase the depressant and analgesic effects of morphine (Kitanaka, Kitanaka, Takemura, 2006; Stockley, 2007), but there is no information of possible interactions with MAOI and propofol (Micromedex, 2016). In this study, mice were pretreated with ayahuasca and then treated with morphine or propofol to verify a possible pharmacological interaction among these agents.

\section{MATERIAL AND METHODS}

\section{Animals}

Male Swiss mice, 3-4 months of age, weighing 30-50 g, were obtained from the Department of Psychobiology, UNIFESP. The animals were kept in an isolated room with a light/dark cycle of $12 \mathrm{~h}$ (7:00 a.m.-7:00 p.m.) at constant temperature $\left(23 \pm 2^{\circ} \mathrm{C}\right)$ and fed ad libitum, except during testing. At the conclusion of the experiments, the animals were euthanized in a $\mathrm{CO}_{2}$ chamber. For the experiment of intestinal transit, the mice were killed by cervical dislocation. This study was approved by the Ethics Committee of UNIFESP (protocol 1494/06) following the standards recommended by the "International Guiding Principles for Biomedical Research Involving Animals" Geneva, 1985.

\section{Drugs, reagents and the preparation of ayahuasca liophilizate}

Commercial samples of propofol (Propovan ${ }^{\circledR}$ ) and morphine sulfate (Dimorf®) were donated by Cristália Laboratory (São Paulo, Brazil). Acetic acid, charcoal, gum arabic and formaldehyde were purchased from Labsynth (São Paulo, Brazil). Propofol and morphine were diluted in saline and administered by intraperitoneal route.

The sample of ayahuasca (AYA) was produced in Manaus (Brazil) and donated by the Associação Benevolente Luz de Salomão according to the ritualistic protocol of this religion. The sample was concentrated and lyophilized (yield of $12 \%$ ). A glass of $70 \mathrm{~mL}$ of ayahuasca (average volume ingested during rituals of this entity) was dried producing $8.4 \mathrm{~g}$ of solid. Therefore, a man of $70 \mathrm{~kg}$ (middle-weight) receives the equivalent of $120 \mathrm{mg} / \mathrm{kg}(8.4$ $\mathrm{g} / 70 \mathrm{~kg}$ ). This dose was chosen as the median unitary dose (1X). Doses equivalent to $0.1 \mathrm{X}(12 \mathrm{mg} / \mathrm{kg})$, the ritualistic $1 X(120 \mathrm{mg} / \mathrm{kg})$ and $10 \mathrm{X}(1200 \mathrm{mg} / \mathrm{kg})$ were chosen for testing in order to increase the chances to observe the behavioral effects, since humans and rodents possess different metabolism, making the dosage transposition complicated.

\section{Determination of the active constituents}

The main active constituents found in ayahuasca (dimethyltryptamine, harmine, harmaline and tetrahydroharmine) were determined as previously described by Pires et al. (2009a).

In summary, the following procedure was performed: a sample solution containing the ayahuasca sample $(0.5 \mathrm{~mL})$, borate buffer $(3.0 \mathrm{~mL}, \mathrm{pH} 9.0)$ and the internal standard diphenhydramine $(100 \mu \mathrm{L}$ of a solution of $1.0 \mathrm{mg} / \mathrm{mL}$ ) was loaded onto a solid-phase extraction C18 cartridge mounted on a vacuum manifold and conditioned with methanol $(2.0 \mathrm{~mL})$, deionized water $(1.0 \mathrm{~mL})$ and borate buffer $(\mathrm{pH} 9.0,2.0 \mathrm{~mL})$. The loaded cartridge was further washed with deionized water (1.0 $\mathrm{mL})$ and a solution of acetonitrile-water $(1: 9,1.0 \mathrm{~mL})$. After drying the cartridges under full vacuum for $7 \mathrm{~min}$, the elution of analytes was performed with methanol $(2.0 \mathrm{~mL})$. Then, $1 \mu \mathrm{L}$ of this solution was injected in a Agilent gas-chromatograph, model 6890, equipped with a nitrogen-phosphorous detector and a 7683 series automatic injector (Little Falls, DE, USA). The analytes 
were identified based on a comparison of its relative retention time with the corresponding values of standards assayed in the same chromatographic run. Quantification was based upon the ratio of the integrated peak area to the internal standard.

\section{Initial pharmacological screening}

Groups of five mice each were treated intraperitoneally (i.p.) or orally (p.o.) by gavage with doses of 12,120 and $1200 \mathrm{mg} / \mathrm{kg}$ of ayahuasca. The controls received the vehicles saline (i.p.) or water (p.o.). The animals were observed at intervals of $30 \mathrm{~min}$ for $4 \mathrm{~h}$ following treatment according to the protocol routinely employed by our group (Pires et al., 2009b; Bezerra et al., 2010). We observed the presence or absence or several signs, such as tremor, palpebral ptosis, muscular tonus, locomotor activity, ataxia, stereotypy, miction, defecation, among others. This experiment was used to establish the doses for subsequent tests and to disclose an initial profile of ayahuasca activity.

\section{Tests to evaluate interaction between ayahuasca and propofol}

A possible interaction between ayahuasca and propofol was evaluated in two behavioral tests: rotarod - to assess the motor coordination; and sleeping time - sedative / hypnotic effect. The doses of propofol employed in each test were chosen based on literature data and pilot studies (data not shown).

\section{Rotarod test}

The performance of mice was measured by evaluating the time they remained on the rotating bar of the rotarod apparatus (AVS Project, Brazil) at a constant speed of $12 \mathrm{rpm}$. The animals were previously selected 24 $\mathrm{h}$ before by eliminating those that could not stay on the bar for $60 \mathrm{~s}$ (Bezerra et al., 2010). First, we evaluated the effect of ayahuasca (120 and $1200 \mathrm{mg} / \mathrm{kg}$, p.o.) or propofol (25, 50 and $100 \mathrm{mg} / \mathrm{kg}$, i.p.) isolated on the motor coordination of mice ( $n=5 /$ group; pilot study). Then, groups of ten mice treated p.o. with water (control) or ayahuasca $1200 \mathrm{mg} /$ $\mathrm{kg}, 30 \mathrm{~min}$ before propofol $(100 \mathrm{mg} / \mathrm{kg}$ ) or saline (both i.p.) were evaluated on the rotarod apparatus at the times 0 (basal), 30, 60 and $120 \mathrm{~min}$. The dose of $1200 \mathrm{mg} / \mathrm{kg}$ of ayahuasca was chosen in order to increase the chance of observing propofol-ayahuasca interaction, since neither 120 nor $1200 \mathrm{mg} / \mathrm{kg}$ affected the mice motor coordination per se.

\section{Sleeping time test}

The doses of propofol were chosen based on pilot study and those described in the literature (Anwar, AbdelRahman, 1998; Xu, Duan, Zeng, 2004). At the pilot study, the sleeping time was evaluated for mice treated i.p. with several doses of propofol ( $n=5 /$ group). Then, groups of 7-10 mice each were pretreated (p.o.) with water (control) or ayahuasca (120 and $1200 \mathrm{mg} / \mathrm{kg}$ ) followed by treatment with propofol (140 or $175 \mathrm{mg} / \mathrm{kg}$, i.p.) $30 \mathrm{~min}$ later. The latency time (time elapsed between propofol administration and the loss of the righting reflex) and the sleeping time (time required for the animal to recover the righting reflex) were recorded (Bezerra et al., 2010).

\section{Tests to evaluate interaction between ayahuasca and morphine}

Three tests were employed to assess both a possible antinociceptive action of ayahuasca and its possible interaction with morphine. A fourth test evaluated the effects of morphine, ayahuasca and their interaction on intestinal transit.

\section{Hot plate test}

Groups of 7-10 mice each were treated p.o. with water (control) or ayahuasca (120 and $1200 \mathrm{mg} / \mathrm{kg}$ ) and after thirty minutes treated by i.p. route with morphine $(10 \mathrm{mg} / \mathrm{kg})$ or saline and then evaluated at 0 (basal), 30, 60, 120 and $240 \mathrm{~min}$ according to Pires et al. (2009b). Each mouse was placed individually on a hot plate (Ugo Basile, Italy) maintained at $55 \pm 1{ }^{\circ} \mathrm{C}$, and the elapsed time required for the animal to produce the characteristic responses to painful stimuli, such as jump or licking their paws, was recorded. Thirty seconds was considered the cut-off time to avoid tissue damage.

\section{Acetic acid writhing test}

Groups of 10 mice each were treated p.o. with water (control) or ayahuasca (120 and $1200 \mathrm{mg} / \mathrm{kg}$ ). Thirty minutes later, morphine $(1 \mathrm{mg} / \mathrm{kg})$ or saline were administered i.p. After an additional $30 \mathrm{~min}, 0.8 \%$ acetic acid was injected (i.p.), and the number of writhings (contractions of the abdomen with distension of the hind legs) was counted over a period of $20 \mathrm{~min}$ (Pires et al., 2009b).

\section{Formalin test}

In the first experiment, mice ( $\mathrm{n}=5-7$ per group) were 
treated p.o. with water (control), ayahuasca (12, 120 and $1200 \mathrm{mg} / \mathrm{kg}$ ) or morphine $(10 \mathrm{mg} / \mathrm{kg}$, i.p.). In the second experiment, mice ( $n=7-9$ per group) received ayahuasca $120 \mathrm{mg} / \mathrm{kg}$ or water (p.o.) and $30 \mathrm{~min}$ later morphine (1 $\mathrm{mg} / \mathrm{kg}$ ) or saline by i.p. route. In both experiments, the test consisted of the subplantar injection of $20 \mu \mathrm{L}$ of formalin $(2.5 \%)$ in the right rear paw 30 min after the last treatment. Behavior was then measured in two periods. The animals were observed to evaluate the reaction to pain, measured as the time spent licking the paw, during the first phase (neurogenic; $0-5 \mathrm{~min}$ ) and the second phase (inflammatory; 15-35 min) (Pires et al., 2009b).

\section{Intestinal transit test}

Groups of five mice each, fasted for $24 \mathrm{~h}$, were treated p.o. with water (control) or ayahuasca (120 and $1200 \mathrm{mg} /$ $\mathrm{kg}$ ), and after $30 \mathrm{~min}$ with morphine $(5 \mathrm{mg} / \mathrm{kg}$ ) or saline by i.p. route. Thirty minutes later, mice were given $0.35 \mathrm{ml}$ (p.o.) of an aqueous suspension of $10 \%$ activated charcoal in 5\% gum arabic. Fifteen minutes later, each animal was killed by cervical dislocation, the small intestine removed and the distance that the charcoal had traveled from the pylorus was measured and expressed as the percentage of the total length of the small intestines (Pires et al., 2009b).

\section{Statistical analysis}

The results are expressed as the mean \pm standard error of mean (SEM). One-way ANOVA followed by Duncan's test was employed to evaluate data with normal distribution: writhes, formalin, intestinal transit and sleeping time tests. Hot plate test (repeated measure) was analyzed by two-way ANOVA followed by Newman Keuls test. Motor coordination was analyzed by the Kruskal-Wallis followed by Mann-Whitney test after found a non-normal distribution. A level of significance of $5 \%(p<0.05)$ was adopted.

\section{RESULTS}

\section{Determination of active constituents}

Tetrahydroharmine $(1.67 \mathrm{mg} / \mathrm{mL})$ was the major constituent found in the ayahuasca sample followed by dimethyltryptamine $(0.38 \mathrm{mg} / \mathrm{mL})$, harmine $(0.32 \mathrm{mg} / \mathrm{mL})$ and harmaline $(0.12 \mathrm{mg} / \mathrm{mL})$.

\section{Initial pharmacological screening with ayahuasca}

Intraperitoneal doses of $120 \mathrm{mg} / \mathrm{kg}$ and $1200 \mathrm{mg} /$ $\mathrm{kg}$ of ayahuasca, under qualitative observation, produced decrease in locomotion and grooming, and increase of sensibility of mice to sound. Intense tremor was observed in the mice treated with $1200 \mathrm{mg} / \mathrm{kg}$. These alterations did not occur with the oral route or were induced in minor intensity. No death was observed.

\section{Rotarod test}

The pilot study with ayahuasca and propofol isolated showed that ayahuasca at 120 and $1200 \mathrm{mg} / \mathrm{kg}$ or propofol at 25 and $50 \mathrm{mg} / \mathrm{kg}$ did not interfere with mice motor coordination, but propofol at dose of $100 \mathrm{mg} / \mathrm{kg}$ reduced the time on rota rod (data not shown). Further, we evaluated the effect of ayahuasca $1200 \mathrm{mg} / \mathrm{kg}$ and Propofol $100 \mathrm{mg} / \mathrm{kg}$ isolated and in association.

As can be seen in Figure 1, ayahuasca $1200 \mathrm{mg} /$ $\mathrm{kg}$, by oral route, did not interfere with mice's capacity to maintain themselves on the rotating bar. On the other hand, propofol $(100 \mathrm{mg} / \mathrm{kg}$, i.p. $)$ greatly reduced the performance of the animals as all of them fell from the rod in less than $20 \mathrm{~s}$ at 15 min after drug administration, but this effect was short-lived as the mice recovered the performance $15 \mathrm{~min}$ later (at 30 min measure). Furthermore, the group treated with ayahuasca + propofol presented motor incoordination at 15 and $30 \mathrm{~min}$, when the effect was no more present on propofol group.

\section{Sleeping time}

The pilot study showed that propofol at doses between 100 and $200 \mathrm{mg} / \mathrm{kg}$ was able to induce sleep in mice (data not shown). As seen in Figure 2 the latency time to sleep was similar among the groups administered with propofol (140 and $175 \mathrm{mg} / \mathrm{kg}$, i.p.). Ayahuasca (120 and $1200 \mathrm{mg} / \mathrm{kg}$, p.o.), somewhat decreased propofol sleeping time, although significance was reached only with the dosage of $120 \mathrm{mg} / \mathrm{kg}$ of ayahuasca plus $175 \mathrm{mg} / \mathrm{kg}$ of propofol. However, this effect was not confirmed with the larger dose of ayahuasca $(1200 \mathrm{mg} / \mathrm{kg})$.

\section{Hot plate test}

As can be seen in Figure 3, morphine induced the expected antinociceptive effect in mice at 30 min when compared with the basal latency, although this effect did not reach significance in the following measurements. Ayahuasca alone (120 and $1200 \mathrm{mg} / \mathrm{kg}$, p.o.) did not change the response time of mice to the hot plate test. The association of ayahuasca $(1200 \mathrm{mg} / \mathrm{kg})$ plus morphine (10 $\mathrm{mg} / \mathrm{kg}$ ) was able to induce the antinociceptive effect at 


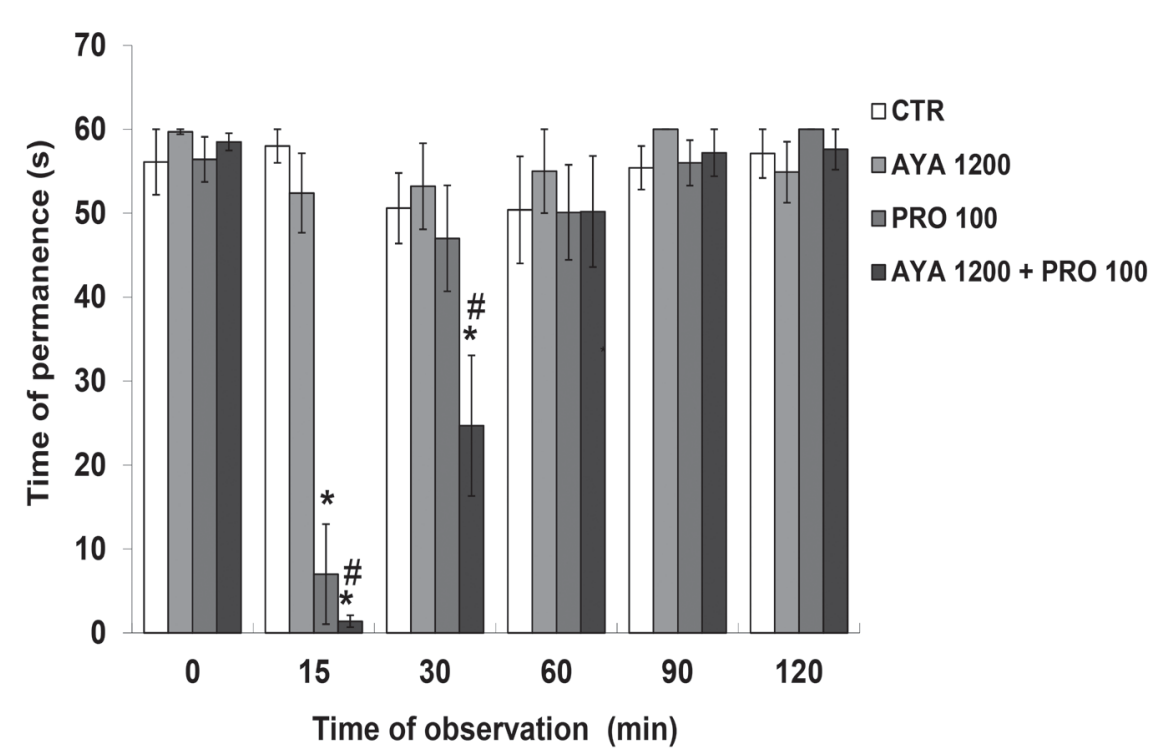

FIGURE 1 - Effect of ayahuasca (AYA, $1200 \mathrm{mg} / \mathrm{kg}$, p.o.) isolated or in association with propofol (PRO, $100 \mathrm{mg} / \mathrm{kg}$, i.p.), on the performance time of mice on the rotating bar. Results are expressed as the mean $\pm \operatorname{SEM}(\mathrm{n}=10) .(*) p<0.05$ : statistically different from control; (\#) $p<0.05$ : statistically different from AYA 1200. Kruskal-Wallis followed by Mann-Whitney.

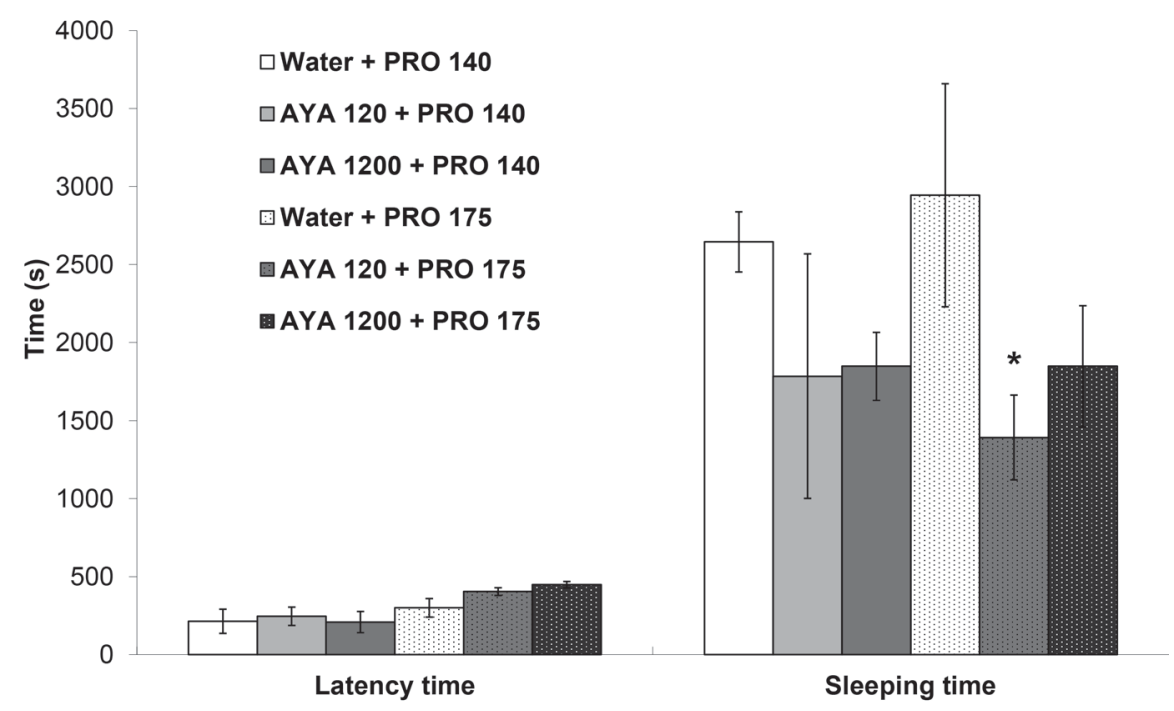

FIGURE 2 - Effect of ayahuasca (AYA, 120 and $1200 \mathrm{mg} / \mathrm{kg}$, p.o.) on the latency time and sleeping time produced by propofol (PRO, 140 and $175 \mathrm{mg} / \mathrm{kg}$, i.p.) in mice. Results are expressed as the mean $\pm \mathrm{SEM}(\mathrm{n}=7-10) .\left(^{*}\right) p<0.05$ : statistically different from group water + propofol $175 \mathrm{mg} / \mathrm{kg}$. ANOVA followed by Duncan's test.

30, 60 and 120 min of observation, while the association with the dose of $120 \mathrm{mg} / \mathrm{kg}$ only reached significance at $120 \mathrm{~min}$. Additionally, the association of ayahuasca (both doses) with morphine significantly increased the latency time at 120 min compared with morphine group or with ayahuasca alone (columns 5 and 6, Figure 3).

\section{Acetic acid writhing test}

Morphine (1 mg/kg, i.p.) significantly reduced the numbers of writhes induced by acetic acid when compared to control mice (Figure 4). Ayahuasca (120 mg/ $\mathrm{kg}$, p.o.) produced no effect per se and did not interfere with the morphine analgesia. However, ayahuasca (1200 $\mathrm{mg} / \mathrm{kg}$, p.o.) produced a significant reduction of writhes (65\%) when compared to control, and the association of ayahuasca $1200 \mathrm{mg} / \mathrm{kg}$ plus morphine $1 \mathrm{mg} / \mathrm{kg}$ showed the most potent analgesic effect (column 6 of Figure 4).

\section{Formalin test}

Figure 5 a shows that $10 \mathrm{mg} / \mathrm{kg}$ of morphine 


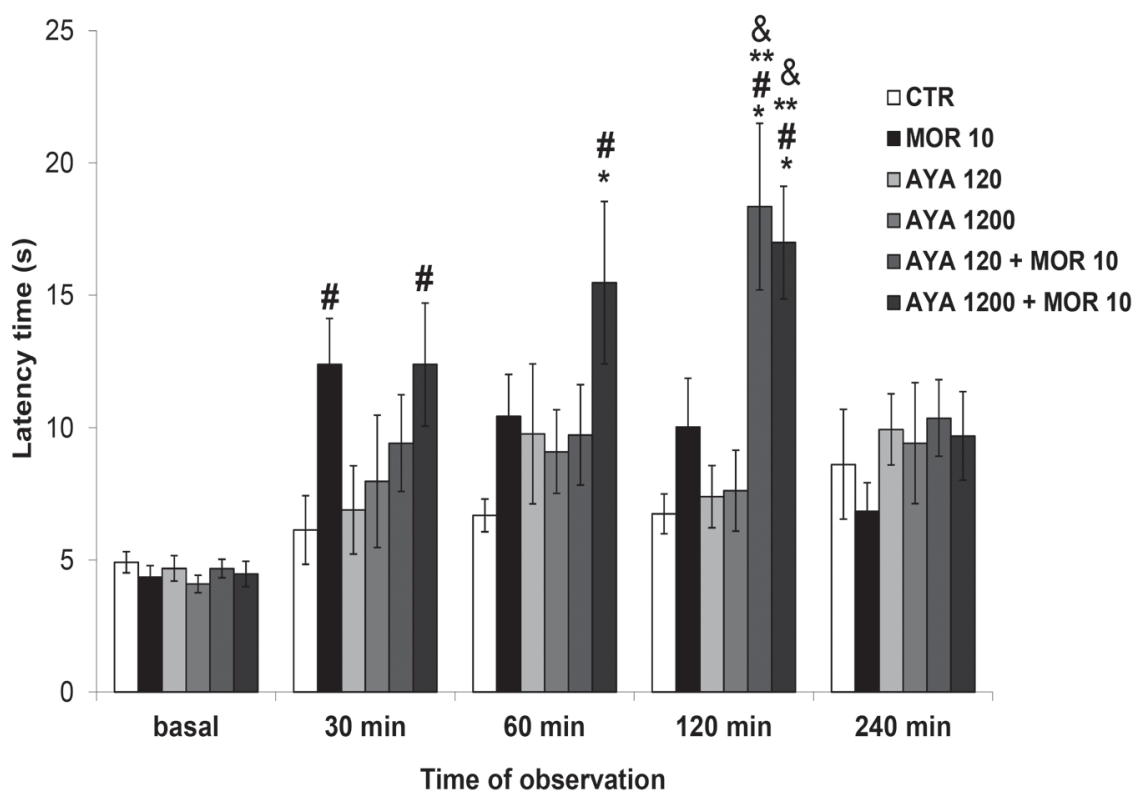

FIGURE 3 - Effect of ayahuasca (AYA, 120 and $1200 \mathrm{mg} / \mathrm{kg}$, p.o.) associated with morphine (MOR, $10 \mathrm{mg} / \mathrm{kg}$, i.p.) on the latency time of mice responding to the thermal stimulus. Results are expressed as the mean $\left.\pm \mathrm{SEM}(\mathrm{n}=7-10) .{ }^{*}\right) p<0.05$ : statistically different from control; (\#) $p<0.05$ : statistically different from corresponding basal; $(* *) p<0.05$ : statistically different from morphine; (\&) $p<0.05$ : statistically different from corresponding dose of ayahuasca at the same observation time. 2-way ANOVA followed by Newman Keuls test.

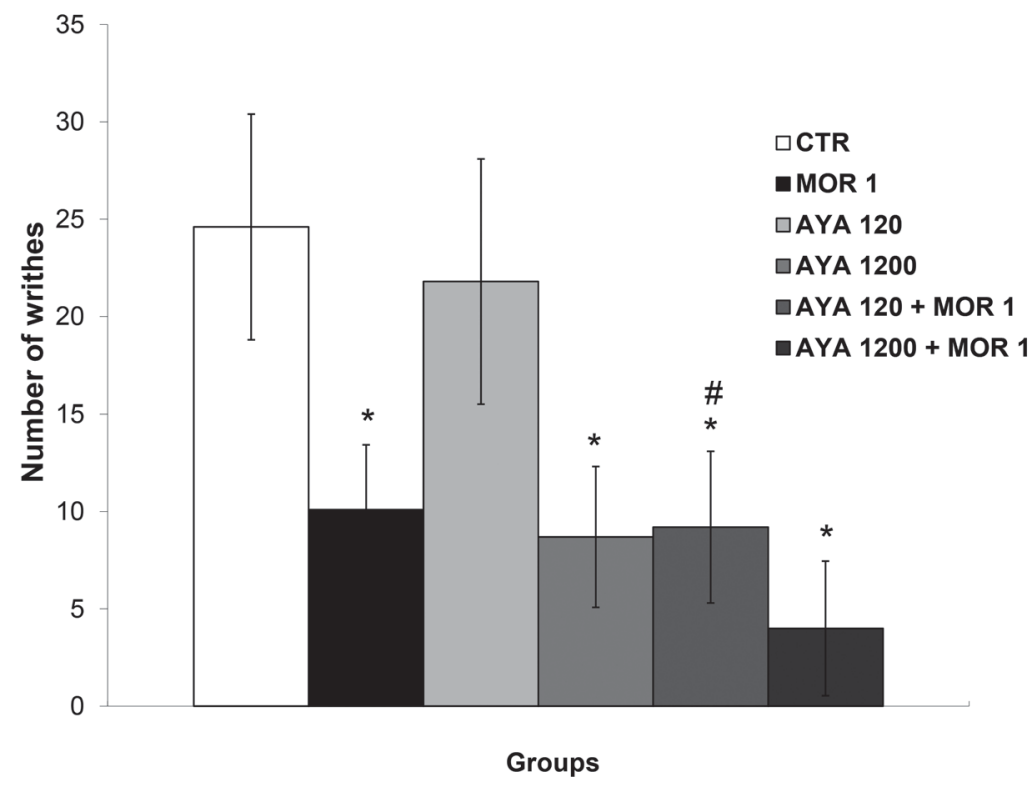

FIGURE 4 - Effect of ayahuasca (AYA, 120 and $1200 \mathrm{mg} / \mathrm{kg}$, p.o.) and its association with morphine (MOR, $1 \mathrm{mg} / \mathrm{kg}$, i.p.) on the number of writhes induced by acetic acid $\left(0.8 \%\right.$, i.p.). Results are expressed as the mean $\pm \operatorname{SEM}(\mathrm{n}=10) .\left({ }^{*}\right) p<0.05$ : statistically different from control; (\#) $p<0.05$ : statistically different from AYA 120. ANOVA followed by Duncan's test.

(i.p.) significantly decreased paw licking during the $1^{\text {st }}$ and $2^{\text {nd }}$ phases by, respectively, 74 and $99 \%$. The groups of mice treated p.o. with 12,120 or $1200 \mathrm{mg} /$ $\mathrm{kg}$ of ayahuasca also showed significant dose-response decrease in the number of writhes in the first phase by, respectively, $35 \%, 42 \%$ and $75 \%$ in relation to the control group. On the other hand, measures taken at the second phase revealed that only the largest dose of ayahuasca $(1200 \mathrm{mg} / \mathrm{kg})$ produced a significant effect (reduction of $95 \%)$. 
Figure $5 \mathrm{~b}$ shows the results of the combination of the sub-effective dose of morphine and ayahuasca. Morphine $(1 \mathrm{mg} / \mathrm{kg}$, i.p.) alone did not diminish significantly the licking time on the first phase, while ayahuasca alone (120 $\mathrm{mg} / \mathrm{kg}$, p.o.) or in combination with morphine $(1 \mathrm{mg} / \mathrm{kg})$ caused a reduction in paw licking during the first phase by $30 \%$ and $38 \%$, respectively. There was no difference among the groups in the second phase, although the mice of morphine group showed a tendency of reduction (34\%) on paw licking response.

\section{Intestinal transit test}

Morphine ( $5 \mathrm{mg} / \mathrm{kg}$, i.p.), as expected, reduced intestinal motility by about $60 \%$, as shown in Table I. Both dosages of ayahuasca were not able to significantly alter intestinal transit or either to interfere with morphine effect.

\section{DISCUSSION}

Several interactions between drugs and herbal
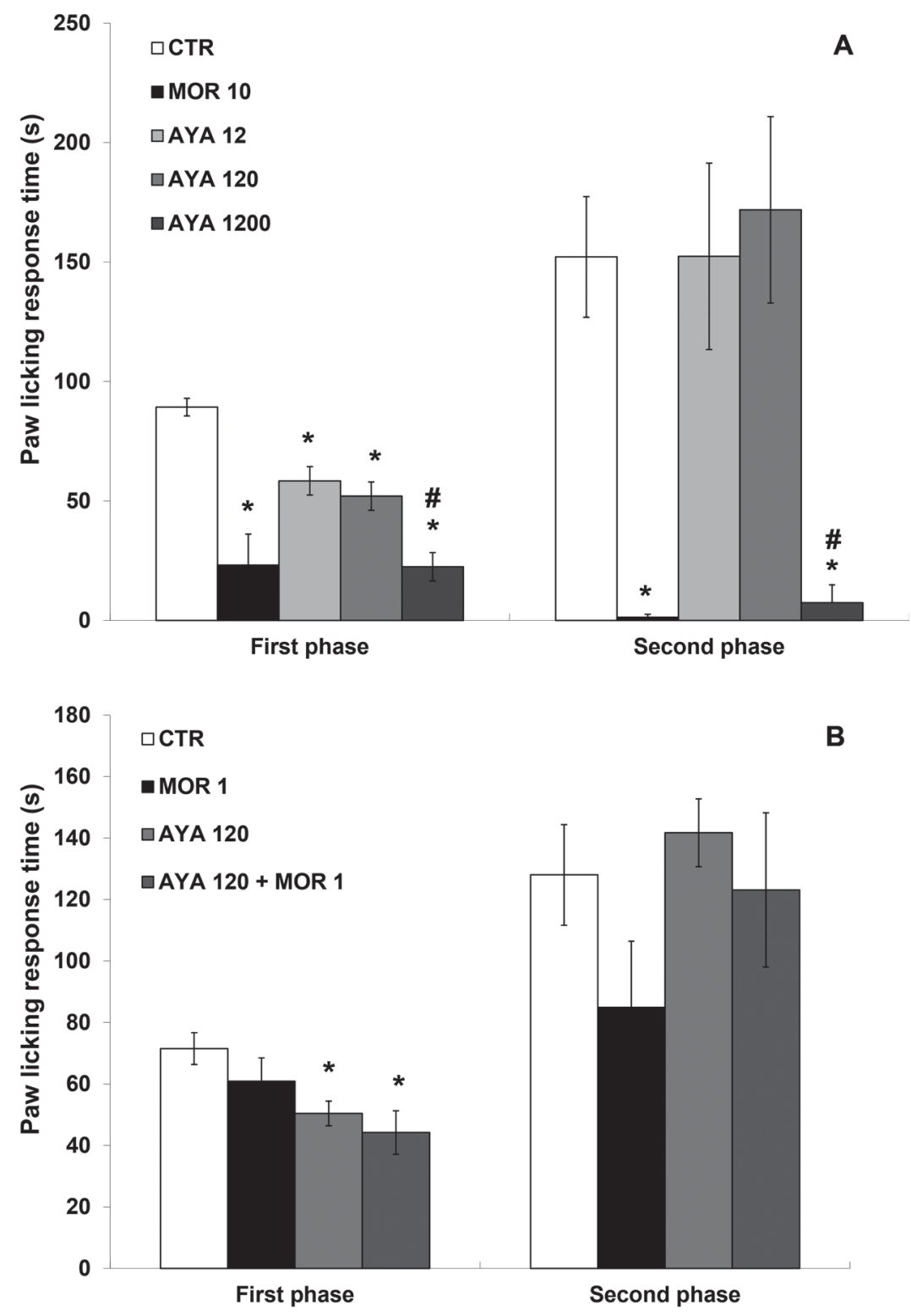

B

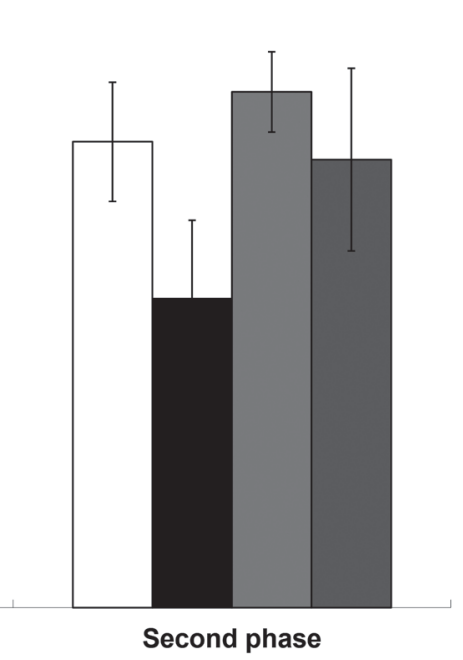

FIGURE 5 - Effect of ayahuasca and morphine on the time that mice spent licking the paw after formalin $2.5 \%$ subplantar injection. A) Ayahuasca (AYA, 12, 120 and $1200 \mathrm{mg} / \mathrm{kg}$, p.o.) and morphine (MOR, $10 \mathrm{mg} / \mathrm{kg}$, i.p.) B) Ayahuasca (AYA, $120 \mathrm{mg} / \mathrm{kg}$, p.o.), morphine (MOR, $1 \mathrm{mg} / \mathrm{kg}$, i.p.) and the respective groups of association. Results are expressed as the mean \pm SEM (A: $\mathrm{n}=5-7$; B: $\mathrm{n}=9-10) .\left({ }^{*}\right) p<0.05$ : statistically different from control; $(\#) p<0.05$ : statistically different from AYA 12 and AYA 120. ANOVA followed by Duncan's test. 
TABLE I - Effect of ayahuasca (120 and $1200 \mathrm{mg} / \mathrm{kg}$, p.o.) and its association with morphine $(5 \mathrm{mg} / \mathrm{kg}$, i.p.) in the distance traveled by activated charcoal in the small intestine (percentage of the total length). Results are expressed as the mean $\pm \operatorname{SEM}(\mathrm{n}=5)$

\begin{tabular}{lc}
\hline Treatment and doses $(\mathbf{m g} / \mathbf{k g})$ & Intestinal transit (\%) \\
\hline Control (water + saline) & $73.1 \pm 8.4$ \\
Water + morphine 5 & $29.5 \pm 2.9^{*}$ \\
Ayahuasca $120+$ saline & $55.9 \pm 8.6$ \\
Ayahuasca $1200+$ saline & $64.7 \pm 1.9$ \\
Ayahuasca $120+$ morphine 5 & $27.3 \pm 5.2^{*}$ \\
Ayahuasca 1200 + morphine 5 & $29.6 \pm 4.2^{*}$ \\
\hline
\end{tabular}

$* p<0.05$ : statistically different from control. ANOVA followed by Duncan's test.

medicines have been reported, such as Hypericum perforatum and Ginkgo biloba (Fugh-Berman, 2000; Roby et al., 2000; Umegaki et al., 2007) and with foods, such as the juices of grapefruit or apples (Farkas, Greenblatt, 2008; Nowack, 2008), which interfere with the $\mathrm{P}_{450}$ enzyme system. The MAOI $\beta$-carbolines present in ayahuasca interfere with the absorption and metabolism of MAO substrates, but the effect of ayahuasca on drugs metabolized by other enzyme system (as $\mathrm{P}_{450}$ ) is poorly known. It was hypothesized that harmaline can alter the metabolic route of 5-methoxy-N-N-dimethyltryptamine (5-MeO-DMT), an analogue of DMT, leading to $\mathrm{CYP}_{2 \mathrm{D} 6}$ metabolism (alternative route) and increasing the production of bufotenine which seems to be more active than 5-MeO-DMT (Jiang et al., 2013; Halberstadt, 2016). However, 5-MeO-DMT is scarcely present in ayahuasca; it was found in trace amounts in some studies, but it was not detectable in most studies with different ayahuasca preparations (McKenna, 2004; McIlhenny et al, 2009; Pires, Oliveira, Yonamine, 2010). Nevertheless, the existence of an alternative route for DMT metabolism under MAO inhibition by $\beta$-carbolines was previously reported (Riba et al., 2012).

The contents of $\beta$-carbolines and DMT in different ayahuasca samples may vary considerably depending on the species and proportion of parts used, method of preparation, time cooking, among other aspects (Rivier, Lindgren, 1972; McKenna, 2004; Callaway, Brito, Neves, 2005; Callaway, 2005). It is known that several species morphologically similar are employed on the tea preparation with alkaloid profiles very distinct (Callaway, 2005; Pires, Oliveira, Yonamine, 2010). Most samples of ayahuasca contain predominant amounts of harmine and tetrahydroharmine, while harmaline, harmalol, harmol and other $\beta$-carbolines are found in low concentration (Callaway, 2003). The concentrations of DMT and $\beta$-carbolines from the sample of ayahuasca used in this study are consistent to those already cited in the literature (Callaway, Brito, Neves, 2005; Callaway, 2005; McIlhenny et al., 2009; Pires, Oliveira, Yonamine, 2010), except for harmine. It is known that additional tetrahydroharmine may be formed from harmine and harmaline during the ayahuasca preparation (Callaway, 2005; McIlhenny et al., 2009). In fact, tetrahydroharmine was the main alkaloid found in our sample. Although less studied than other $\beta$-carbolines, THH is also described as a weaker MAO inhibitor, but it can increase serotonin concentration by inhibiting serotonin reuptake and has longer half-life (Callaway, 2003; Domínguez-Clavé et al., 2016).

Ayahuasca when administered as a lyophilizate to mice, either by intraperitoneal route or orally, revealed to be a safe drug since gross behavioral alterations were observed only with dose of $1200 \mathrm{mg} / \mathrm{kg}$ (10X the ritualistic), corroborating with previous studies in rodents (Pic-Taylor et al., 2015). In fact, ayahuasca is considered safe when used alone in the religious contexts (McKenna, 2004; Gable, 2007). However, the association of any psychotropic drugs must be considered with caution, including plants. Leak (2000) warns that the use of Hypericum perforatum, Piper methysticum and Valeriana officinalis during the perioperative period may affect anesthesia. It is suggested that the anesthesiologists should ask their presurgical patients about any medications they are taking, including herbal supplements and other alternative substances, and should decide about the discontinuation of the supplements when necessary, since these products can interfere with anesthesia and potentially cause complications during surgery (Kaye et al., 2007; Whinney, 2009; Abe et al., 2014).

The results of this study suggest an interaction between ayahuasca (at doses of 1 to 10 times the used in rituals) with morphine and propofol, verified by the modification of the isolated effects of these drugs. The dose of $12 \mathrm{mg} / \mathrm{kg}$ of ayahuasca (0.1X the ritual) was not evaluated in association with morphine or propofol because it presented only minor effects. Ayahuasca at the dose of $1200 \mathrm{mg} / \mathrm{kg}$ was able to increase the effect of propofol in the rotarod test and to decrease the propofolinduced sleeping time. The results obtained in the interaction of ayahuasca with propofol seem contradictory, i.e., increased incoordination and decreased sleeping time. However, this result agrees with the personal information of ayahuasca users who report that the decoction produces body relaxation, but induces lack of sleep. Ayahuasca, as a MAOI, increases the central levels 
of noradrenaline and serotonin which may increase the activation of the ascending reticular activating system. In our study, ayahuasca did not alter sleeping time and motor coordination per se, but altered the propofol effect. Propofol causes fast muscle relaxation but it is not considered a good hypnotic drug, instead, it is employed as a sedative and as an adjuvant in inducing and maintenance of anesthesia (McKeage, Perry, 2003). Since the effects of ayahuasca and propofol interaction were opposite on the two tests, we can hypothesize that these effects may be mediated by different pathways, but our current data is not enough to propose the mechanisms of interaction.

Furthermore, ayahuasca revealed to possess analgesic effect per se. Thus, the dose of $1200 \mathrm{mg} / \mathrm{kg}$ decreased the number of writhes of mice challenged with acetic acid and decreased the paw licking of mice in the first phase (0-5 min) on formalin test. In this respect it is interesting that extracts of Peganum harmala, containing high concentration of harmaline, showed antinociception in the formalin test (Monsef et al., 2004), corroborating with our data. The previous administration of 120 or 1200 $\mathrm{mg} / \mathrm{kg}$ of ayahuasca to mice prolonged the morphine analgesia as measured through the hot plate test. This data would suggest a synergic effect of ayahuasca, perhaps inhibiting the morphine metabolism. Clorgyline, a MAOI, potentiated morphine-induced antinociception in tail flick test, but not in the hot plate test (Kitanaka, Kitanaka, Takemura, 2006). On the other hand, ayahuasca was not able to increase morphine analgesia in formalin test, although it has been active by itself (Figure 5). Because ayahuasca per se was not active on thermal nociception and did not alter the intestinal transit, it is possible that ayahuasca acts by a non-opioid mechanism, possibly by anti-inflammatory process. Another hypothesis is that ayahuasca analgesic effect depend on the central serotonergic modulation and/or endogenous opioid release which are reached on specific time points.

The $\beta$-carbolines exert a plenty of neurophysiological effects such as competitive inhibition of monoamines uptake, inhibition of $\mathrm{Na}^{+}$-dependent ATPases, among others (for a review, see McKenna, 2004). Interestingly, harman and harmine attenuated some signs of naloxoneprecipitated morphine withdrawal syndrome (AriciogluKartal, Kayir, Uzbay, 2003), what corroborate with the hypothesis that these alkaloids may modulate the opioid system. The authors suggested that the beneficial effects may be mediated by imidazoline receptors, what was later evaluated by Miralles et al. (2005) that demonstrated the $\beta$-carbolines bind with high affinity to imidazoline I2B receptors. However, further studies are needed in order to evaluate the antinociceptive effect of ayahuasca in the presence and absence of antagonists to better elucidate its mechanism of action. Ayahuasca interactions with propofol in the antinociceptive tests were not evaluated because the analgesic effect after propofol acute administration is too short (Anwar, Abdel-Rahman, 1998; Rahman, Hashim, 2011).

Taken together, the set of results showed that the oral pre-treatment with ayahuasca in doses from 1 to 10 times the used in rituals $(120-1200 \mathrm{mg} / \mathrm{kg})$ modified some effects of intraperitoneal administration of morphine and propofol. The use of morphine and propofol by i.p. route in our study limits the translation of our results to humans since the intravenous administration leads to faster and more potent effects. However, some pharmacokinetic interactions cannot be discarded. For instance, the finding that ayahuasca increased and extended the effect of morphine on the hot plate suggests that ayahuasca may reduce its metabolism.

In summary, the present study shows that the lyophilizate of ayahuasca decoction modified the analgesic effects of morphine in mice depending on the test employed. Furthermore, the muscle relaxant effect of propofol in the rotarod was prolonged, while its sedative effect seemed reduced. These data suggest that anesthetists should take some caution when using morphine or propofol in followers of ayahuasca cults undergoing surgical procedures. More studies are needed to better investigate the interactions between ayahuasca and morphine/propofol, and pharmacokinetic studies are suggested to address this question.

\section{ACKNOWLEDGMENTS}

The authors are grateful to Rilton R. Guiso for collaborating with information about the use of ayahuasca beverage and Dr. Wilson Gonzaga for donating the sample of ayahuasca. We also thank the Laboratory Cristália for the donation of morphine and propofol. This study was supported by FAPESP (\#2008/52904-2) and Associação Fundo de Incentivo à Pesquisa (AFIP).

\section{CONFLICTS OF INTEREST}

The authors declare no conflict of interest.

\section{REFERENCES}

Abe A, Kaye AD, Gritsenko K, Urman RD, Kaye AM. Perioperative analgesia and the effects of dietary supplements. Best Pract Res Clin Anaesthesiol. 2014;28(2):183-9. 
Anwar MM, Abdel-Rahman MS. Effect of propofol on perception of pain in mice: mechanisms of action. Comp Biochem Physiol A Mol Integr Physiol. 1998;120(2):249-53.

Aricioglu-Kartal F, Kayir H, Uzbay IT. Effects of harman and harmine on naloxone-precipitated withdrawal syndrome in morphine-dependent rats. Life Sci. 2003;73(18):2363-71.

Bezerra AG, Mendes FR, Tabach R, Carlini EA. Effects of a hydroalcoholic extract of Turnera difusa in tests for adaptogenic activity. Rev Bras Farmacog. 2010;21(1):121-7.

Callaway JC, Brito GS, Neves ES. Phytochemical analyses of Banisteriopsis caapi and Psychotria viridis. J Psychoactive Drugs. 2005;37(2):145-50.

Callaway JC, Grob CS. Ayahuasca preparations and serotonin reuptake inhibitors: a potential combination for severe adverse interactions. J Psychoactive Drugs. 1998;30(4):367-9.

Callaway JC. A review of ayahuasca phytochemistry and neuropharmacology. Arq Bras Fitomed Cient. 2003;1:134-42.

Callaway JC. Fast and slow metabolizers of Hoasca. J Psychoactive Drugs. 2005;37(2):157-61.

Callaway JC. Various alkaloid profiles in decoctions of Banisteriopsis caapi. J Psychoactive Drugs. 2005;37(2):151-5.

Castro-Neto EF, da Cunha RH, Dartiu da Silveira DX, Yonamine M, Gouveia TLF, Cavalheiro EA, et al. Changes in aminoacidergic and monoaminergic neurotransmission in the hippocampus and amygdala of rats after ayahuasca ingestion. World J Biol Chem. 2013;4(4):141-7.

Domínguez-Clavé E, Soler J, Elice M, Juan C, JC, Álvarez E, Revenga MF, et al. Ayahuasca: pharmacology, neuroscience and therapeutic potential. Brain Res Bull. 2016;126(Pt. 1):89-101.

Farkas D, Greenblatt DJ. Influence of fruit juices on drug disposition: discrepancies between in vitro and clinical studies. Expert Opin Drug Metab Toxicol. 2008;4(4):381-93.

Frecska E, Bokor P, Winkelman M. The therapeutic potentials of ayahuasca: possible effects against various diseases of civilization. Front Pharmacol. 2016;7:35. Doi: 10.3389/ fphar.2016.00035.

Fugh-Berman A. Herb-drug interactions. Lancet. 2000;355(9198):134-138.
Gable RS. Risk assessment of ritual use of oral dimethyltryptamine (DMT) and harmala alkaloids. Addiction. 2007;102(1):24-34.

Halberstadt AL. Behavioral and pharmacokinetic interactions between monoamine oxidase inhibitors and the hallucinogen 5-methoxy- $N, N$-dimethyltryptamine. Pharmacol Biochem Behav. 2016;143:1-10.

Jiang XL, Shen HW, Mager DE, Yu AM. Pharmacokinetic interactions between monoamine oxidase A inhibitor harmaline and 5-methoxy-N,N-dimethyltryptamine, and the impact of CYP2D6 status. Drug Metab Dispos. 2013;41(5):975-86.

Kaye AD, Baluch A, Kaye AJ, Frass M, Hofbauer R. Pharmacology of herbals and their impact in anesthesia. Curr Opin Anaesthesiol. 2007;20(4):294-9.

Kitanaka N, Kitanaka J, Takemura M. Modification of morphine-induced hyperlocomotion and antinociception in mice by clorgyline, a monoamine oxidase-A inhibitor. Neurochem Res. 2006;31(6):829-37.

Labate BC, Feeney K. Ayahuasca and the process of regulation in Brazil and internationally: implications and challenges. Int $\mathrm{J}$ Drug Policy. 2012;23(2):154-61.

Leak JA. Perioperative considerations in the management of the patient taking herbal medicines. Curr Opin Anaesthesiol. 2000;13(3):321-5.

McIhenny EH, Pipkin KE, Standish LJ, Wechkin HA, Strassman R, Barker SA. Direct analysis of psychoactive tryptamine and harmala alkaloids in the Amazonian botanical medicine ayahuasca by liquid chromatography-electrospray ionization-tandem mass spectrometry. J Chromatogr A. 2009;1216(51):8960-8.

McKeage K, Perry CM. Propofol: a review of its use in intensive care sedation of adults. CNS Drugs. 2003;17(4):235-72.

McKenna DJ, Towers GHN, Abbott F. Monoamine oxidase inhibitors in South American hallucinogenic plants: tryptamine and $\beta$-carboline constituents of ayahuasca. J Ethnopharmacol. 1984;10(2):195-223.

McKenna DJ. Clinical investigations of the therapeutic potential of ayahuasca: rationale and regulatory challenges. Pharmacol Ther. 2004;102(2):111-29. 
Micromedex Healthcare Series [Internet]. Drug Interactions. [Accessed on 2016 May] Greenwood Village, Colo: Thomson Healthcare. Available from: http://www.micromedexsolutions. $\mathrm{com} /$.

Miralles A, Esteban S, Sastre-Coll A, Moranta D, Asensio VJ, García-Sevilla JA. High-affinity binding of beta-carbolines to imidazoline $\mathrm{I} 2 \mathrm{~B}$ receptors and $\mathrm{MAO}-\mathrm{A}$ in rat tissues: norharman blocks the effect of morphine withdrawal on DOPA/noradrenaline synthesis in the brain. Eur J Pharmacol. 2005;518(2-3):334-42.

Monsef HR, Ghobadi A, Iranshahi M, Abdollahi M. Antinociceptive effects of Peganum harmala L. alkaloid extract on mouse formalin test. J Pharm Pharm Sci. 2004;7(1):65-9.

Nowack R. Review article: cytochrome P450 enzyme, and transport protein mediated herb-drug interactions in renal transplant patients: grapefruit juice, St John's Wort - and beyond! Nephrology (Carlton). 2008;13(4):337-47.

Pic-Taylor A, Motta LG, Morais JA, Junior WM, Santos AFA, Campos LA et al. Behavioural and neurotoxic effects of ayahuasca infusion (Banisteriopsis caapi and Psychotria viridis) in female Wistar rats. Behav Processes. 2015;118:102-110.

Pires AP, De Oliveira CD, Moura S, Dörr FA, Silva WA, Yonamine M. Gas chromatographic analysis of dimethyltryptamine and beta-carboline alkaloids in ayahuasca, an Amazonian psychoactive plant beverage. Phytochem Anal. 2009a;20(2):149-53.

Pires AP, Oliveira CDR, Yonamine M. Ayahuasca: uma revisão dos aspectos farmacológicos e toxicológicos. Rev Ciênc Farm Básica Apl. 2010;31(1):15-23.

Pires JM, Mendes FR, Duarte-Almeida JM, Negri G, Carlini EA. Antinociceptive peripheral effect of Achillea millefolium L. and Artemisia vulgaris L.: both plants known popularly by brand names of analgesic drugs. Phytother Res. 2009b;23(2):212-9.

Rahman NHNA, Hashim A. The use of propofol for procedural sedation and analgesia in the emergency department: a comparison with midazolam. Emerg Med J. 2011;28(10):861-5.
Riba J, McIlhenny EH, Valle M, Bouso, JC, Barker AS. Metabolism and disposition of $N, N$-dimethyltryptamine and harmala alkaloids after oral administration of ayahuasca. Drug Test Anal. 2012;4(7-8):610-6.

Rivier L, Lindgren JE. "Ayahuasca," the South American hallucinogenic drink: an ethnobotanical and chemical investigation. Econ Bot. 1972;26(2):101-29.

Roby CA, Anderson GD, Kantor E, Dryer DA, Burstein AH. St John's wort: effect on CYP3A4 activity. Clin Pharmacol Ther. 2000;67(5):451-7.

Santos RG, Landeira-Fernandez J, Strassman RJ, Motta V, Cruz APM. Effects of ayahuasca on psychometric measures of anxiety, panic-like and hopelessness in Santo Daime members. J Ethnopharmacol. 2007;112(3):507-13.

Santos RG, Osório FL, Crippa JAS, Hallak JEC. Antidepressive and anxiolytic effects of ayahuasca: a systematic literature review of animal and human studies. Rev Bras Psiquiatr. 2016;38(1):65-72.

Stockley IH. Interacciones farmacológicas. 2nd ed. Barcelona: Pharma Editores; 2007.

Umegaki K, Taki Y, Endoh K, Taku K, Tanabe H. Bilobalide in Ginkgo biloba extract is a major substance inducing hepatic CYPs. J Pharm Pharmacol. 2007;59(6):871-7.

Whinney C. Perioperative medication management: general principles and practical applications. Cleve Clin J Med. 2009;76(Suppl 4):S126-32.

Xu AJ, Duan SM, Zeng YM. Effects of intrathecal NMDA and AMPA receptors agonists or antagonists on antinociception of propofol. Acta Pharmacol Sin. 2004;25(1):9-14.

Received for publication on $11^{\text {st }}$ April 2017 Accepted for publication on $02^{\text {nd }}$ October 2017 